\title{
ANALISIS KELAYAKAN USAHA BUDIDAYA IKAN LELE SANGKURIANG MENGGUNAKAN TEKNOLOGI BIOFLOK (Studi Kasus Pada Dua Pembudidaya Lele Sangkuriang (Clrarias gariepinus) di Kecamatan Jekan Raya Kota Palangka Raya)
}

\author{
${ }^{1}$ Andre Julpano, ${ }^{2}$ A. Zaki Yamani, ${ }^{3}$ Sunariyo
}

\author{
${ }^{1}$ Alumnus Program Studi Agribisnis Fakultas Pertanian Universitas Palangka Raya \\ ${ }^{2,3}$ Staf Pengajar Program Studi Agribisnis Fakultas Pertanian Univesitas Palangka Raya
}

\begin{abstract}
ABSTRAK
Penelitian ini dilakukan untuk mengetahui kelayakan usaha budidaya ikan lele sangkuriang menggunakan teknologi bioflok di Kecamatan Jekan Raya Kota Palangka Raya, metode pengolahan data pada penelitian ini adalah deskriptif kualitatif, alat analisis yang digunakan adalah analisis kelayakan usaha budidaya dengan kriteria R/C rasio, B/C Rasio, Break Event Point, dan Payback Pariod. Teknik pengambilan sampel dilakukan dengan Sawball sampling. Hasil analisis menunjukan kelayakan usaha Pembudidaya I: $\mathrm{R} / \mathrm{C}=2,3>1$; $\mathrm{B} / \mathrm{C}=1,8>1$, BEP produksi $1.334 \mathrm{Kg}$, BEP harga sebesar Rp.12.511 dan Payback Pariod selama 4 bulan, sedangkan hasil analisis kelayakan usaha Pembudidaya II: $\mathrm{R} / \mathrm{C}=2,1>1$; $\mathrm{B} / \mathrm{C}=1,1>1$, BEP produksi sebesar 2.186 Kg, BEP Harga sebesar Rp.11.388 Payback Pariod selama 3,2 bulan. Berdasarkan hasil analisis kelaykanan tersebut maka usaha budidaya ikan lele sangkuriang yang dilakukan oleh kedua pembudidaya layak dan menguntungkan.

Kata Kunci : analisis kelayakan usaha budidaya, siklus produksi, teknologi bioflok,
\end{abstract}

\begin{abstract}
ABSTRCT
The research use done knowing feasibility analysis cultivation of cat fish use technology bioflok the district Jekan Raya in Palangka Raya city, the method processing of data as descriptive quantitative, analysis toll use a feasibility analysis cultivation with criteria as R/C ratio, B/C ratio, Break Event Point, dan Payback Pariod. The technique sampling in research is a Snawball sampling. The results of feasibility analysis first cultivation is $\mathrm{R} / \mathrm{C}=2,3>1 ; \mathrm{B} / \mathrm{C}=1,3>1$; $\mathrm{BEP}$ production as $1.334 \mathrm{Kg}$, BEP price of Rp. 12.511 and Payback Pariod during 4 month's The results of feasibility analysis sound cultivation is $\mathrm{R} / \mathrm{C}=2,1>1 ; \mathrm{B} / \mathrm{C}=1,1>1$, BEP production as $2.186 \mathrm{Kg}$; BEP price of Rp. 11.388, and Payback Pariod during 3,2 month's
\end{abstract}

Keyword : feasibility analysis cultivation, production siclus, biofloc technology.

\section{Latar Belakang}

\section{PENDAHULUAN}

Pembangunan

berkelanjutan (Sustainable Fisheries)

sebagai aktivitas perikanan yang dilakukan sedemikian rupa sehingga dapat berlangsung terus menerus pada tingkat yang wajar dan memperhatikan kesehatan ekologi, meminimalkan efek samping yang 
mengganggu keanekaragaman, struktur, dan fungsi ekosistem. Pembangunan perikanan berkelanjutan melalui sub sektor perikanan perlu dilakukan, karena sumberdaya perikanan Indonesia merupakan aset pembangunan yang memiliki peluang besar untuk dijadikan sumber pertumbuhan ekonomi.

Pembanguan perikanan pada dasarnya dititik beratkan pada perikanan tangkap dan perikanan budidaya. Usaha kearah pembudidayaan ikan di perairan umum sangat diperlukan sebagai penyeimbang dan pembantu pemenuhan produksi ikan yang selama ini diperoleh dari hasil perikanan tangkap yang cenderung semakin menurun. Seiring dengan berkembangnya zaman dan meningkatnya pertambahan penduduk membuat kebutuhan protein semakin meningkat setiap tahunnya, maka perlu adanya peningkatan produksi ikan sebagai salah satu sumber pangan dan sumber protein, peningkatan produksi perikanan tersebut dapat dilakukan melalui kegiatan budidaya ikan.

Tabel 1 Produksi Budidaya Ikan Menurut Jenis Usaha di Kota Palangka Raya Tahun 2017

\begin{tabular}{lcrrrr}
\hline \multirow{2}{*}{ No. } & \multirow{2}{*}{ Kecamatan } & \multicolumn{3}{c}{ Jenis Usaha Budidaya } & Jumlah \\
\cline { 3 - 5 } & & Kolam & Karamba & KJA & (ton) \\
\hline 1. & Pahandut & $1.219,34$ & $8.149,82$ & 1,33 & $9.370,49$ \\
2. & Jekan Raya & $3.277,41$ & 268,90 & 1.24 & $3.548,35$ \\
3. & Sabangau & $2.508,96$ & 155,38 & - & $2.664,34$ \\
4. & Bukit Batu & 868.43 & 16,30 & 0,18 & 884,91 \\
5. & Rakumpit & 70,94 & 40,69 & - & 111,63 \\
\hline & Jumlah & $7.945,08$ & $8.631,09$ & 3,55 & $16.579,72$ \\
\hline
\end{tabular}

Sumber : Dinas Perikanan Kota Palangka Raya, 2018

Tabel 1 menunjukan total produksi usaha budidaya ikan dalam kolam dari lima kecamatan sebesar
Salah satu jenis ikan yang dibudidaya adalah ikan lele, perkembangan usaha budidaya ikan lele di daerah ini cukup pesat jika dilihat dari jumlah produksi yang dihasilkan oleh tiap - tiap kabupaten, terdapat berbagai daerah yang digunakan untuk budidaya ikan lele diantaranya adalah Kota Palangka Raya, dalam bidang perikanan Kota Madya ini mempunyai prospek cukup potensial untuk dikembangkan, dikarenakan pada lima kecamatan di kota ini seperti Kecamatan Pahandut, Jekan Raya, Sabangau, Bukit Batu, dan Rakumpit melakukan usaha budidaya ikan pada sistem budidaya dalam kolam, karamba dan KJA.

Kolam merupakan salah satu sarana budidaya ikan yang penting untuk menunjang keberhasilan budidaya ikan khususnya perikanan darat. Kolam merupakan media atau wadah air yang digunakan untuk ikan hidup sehingga diusahakan semirip mungkin dengan kondisi alami lingkungan ikan di alam bebas. Berikut ini jumlah produksi usaha budidaya ikan pada ditiap - tiap kecamatan di Kota Palangka Raya : 
$2.508,96$ ton atau $31 \%$, Pahandut $1.219,34$ ton atau $15 \%$, Bukit Batu 868.43 ton atau $10 \%$ dan Rakumpit 70,94 ton atau $3 \%$.

Ikan lele merupakan komoditas ikan air tawar yang populer Tabel 2 Produksi Usaha Budidaya Ikan Per Jenis Ikan Tahun 2018

\begin{tabular}{llrrrr}
\multirow{2}{*}{ No. } & \multirow{2}{*}{ Jenis Ikan } & \multicolumn{3}{c}{ Jenis Usaha Budidaya } & \multirow{2}{*}{$\begin{array}{c}\text { Jumlah } \\
\text { (ton) }\end{array}$} \\
\cline { 2 - 5 } 1 & Mas & - & 1.406, & - & $1.406,10$ \\
2 & Nila & $1.332,71$ & $3.159,48$ & 1,10 & $4.493,29$ \\
3 & Gurame & 610.97 & 88,48 & - & 699,45 \\
4 & Patin & $3.710,28$ & $3.711,06$ & & $7.422,82$ \\
$\mathbf{5}$ & Lele & $\mathbf{2 . 2 2 9 , 2 2}$ & - & - & $\mathbf{2 . 2 2 9 , 2 2}$ \\
6 & Bawal & - & 29,67 & - & 29,67 \\
7 & Toman & - & 129,27 & - & 129,27 \\
8. & Baung & - & 72,29 & - & 72,29 \\
9 & Betok & 61,90 & - & 0,97 & 62,87 \\
10 & Gabus & - & 1,57 & - & 1,57 \\
11 & Ikan & - & 20,43 & - & 9,77 \\
& Lainnya & \multicolumn{5}{c}{ KJaramba } & & \\
\hline & Jumlah & $7.945,08$ & $8.631,09$ & 3,55 & $16.579,72$ \\
\hline
\end{tabular}

Sumber : Dinas Perikanan Kota Palangka Raya, 2019
Dari Tabel 2 diatas dapat dilihat bahwa jumlah produksi budidaya ikan sebesar $16.579,72$ ton, dari total produksi tersebut terdapat produksi dalam kolam kolam sebesar 7.945,08 ton, dimana kontribusi produksi ikan lele dari jumlah produksi sebesar 2.229,22 ton yaitu $28 \%$ yang menenpati urutan kedua, sedangkan untuk urutan pertama terdapat pada ikan patin yang mempunyai jumlah produksi sebesar $3.710,28$ ton atau $46 \%$.

Kemajuan teknologi dapat memberikan dampak yang positif bagi masyarakat khusnya pada usaha budidaya ikan lele, dari kemajuan teknologi tersebut ditemukan cara budidaya ikan lele sangkuriang yang dapat dilakukan di lahan sempit dengan perawatan yang lebih mudah, teknologi tersebut dimanakan dengan istilah bioflok. Kecamatan Jekan dimasyarakat selain mudah dibudidayakan, untuk dikosumsi dan ikan ini juga mempunyai harganya yang relatif murah, produksi ikan lele dapat dilihat pada Tabel di bawah ini
Raya merupakan salah satu dari lima kecamatan yang ada di Kota Palangka Raya dimana kecamatan ini melakukan usaha budidaya ikan lele sangkuriang pada kolam bioflok yang sedang dikembangkan, sehingga untuk mengetahui keberhasilan dalam menerapkan teknologi bioflok dalam kegiatan usaha budidaya ini, maka cara budidaya dengan teknologi ini perlu dianalisis kelayakan usaha budidayanya dari tingkat keuntunan dan manfaat usaha tersebut. Ada beberapa kriteria yang menjadi indikator kelayakan usaha budidaya antara lain $\mathrm{R} / \mathrm{C}$ ratio, $\mathrm{B} / \mathrm{C}$ ratio, Break Event Point (BEP), Payback Pariod.

\section{METODE PENELITIAN}

Penelitian ini dilaksanakan pada Kecamatan Jekan Raya, Kota Palangka Raya, pemilihan lokasi penelitian dilakukan secara sengaja 
(purposive sampling) berdasarkan pertimbangan bahwa Kecamatan Jekan Raya mempunyai usaha budidaya ikan lele dalam kolam bioflok yang sedang dikembangkan, penelitian dilaksanakan selama 3 bulan mulai dari bulan November Januari 2020.

Berdasarkan hasil survei ditemukan bahwa dari jumlah pembudidaya ikan pada usaha budidaya dalam kolam sebanyak 298 pembudidaya tidak semuanya aktif dalam kegiatan usaha budidaya dikarenakan berbagai macam permasalahan dan kendala, sehingga teknik pengambilan sampel dalam penelitian ini adalah teknik snowball sampling, yang bertujuan untuk memperoleh jumlah sampel petani pada kolam khususnya bioflok dan diperoleh dua Petani yang aktif mengusahakan ikan lele sangkuriang menggunakan teknologi bioflok yaitu Pembudidaya I dan Pembudidaya II

Untuk menjawab tujuan pertama digunakan analisis deskriptif. Untuk menjawab tujuan kedua yaitu menganalisis kelayakan usaha budidaya ikan lele sangkuriang yang dilakukan oleh Pembudidaya I dan Pembudidaya II menggunakan teknologi bioflok, berikut rumus yang digunakan dalam melihat kelayakan usaha budidaya ikan lele sangkuriang antara lain sebagai tersebut

\section{Biaya Usaha Budidaya}

Menurut Soekartawi (2006) biaya usaha digolongkan menjadi tiga jenis yaitu biaya tetap, biaya variabel, dan biaya penyusutan alat usaha, untuk menghitung penyusutan alat usaha dapat dirumuskan sebagai berikut :

$$
\frac{\text { nilai perolehan }- \text { nilai sisa }}{\text { umur ekonomis }}
$$

\section{Penerimaan Usaha}

Dalam Soekartawi (2006) besarnya penerimaan usaha dapat dihitung dengan rumus sebagai beriku

dimana:

$$
\text { TR = Y.Py }
$$

$\mathrm{TR}=$ total revenue

$\mathrm{Y} \quad=$ tingkat output

Py = harga output.

\section{Pendapatan Usaha}

Soekartawi (2006) Pendapatan usaha budidaya dapat dihitung menggunakan rumus sebagai berikut:

$$
\text { Pd }=\text { TR- TC }
$$

Keterangan :

$\mathrm{Pd} \quad=$ pendapatan usahatani

$\mathrm{TR}=$ total penerimaan

$\mathrm{TC}=$ total biaya

\section{Penerimaan Atas Biaya (R/C Rasio)}

Analisis ini digunakan untuk melihat perbandingan total penerimaan dengan total biaya usaha, dengan kriteria hasil :

1. $\mathrm{R} / \mathrm{C}>1$ berarti usaha layak untuk dijalankan.

2. $\mathrm{R} / \mathrm{C}=1$ berarti usaha yang dijalankan dalam kondisi titik impas.

3. $\mathrm{R} / \mathrm{C}<1$ usaha tidak menguntungkan dan tidak layak.

Secara sistematis $R / C$ rasio dapat dirumuskan sebagai berikut :

$$
\mathrm{R} / \mathrm{C}=
$$

total penerimaan usaha budidaya lele sangkuriang

total biaya usaha budidaya lele sangkuriang

\section{Manfaat Atas Biaya (B/C Ratio)}

Analisis ini digunakan untuk melihat manfaat usaha dari biaya yang dikeluarkan dengan kriteria kelayakan sebagai berikut: 
1. $B / C>1$ berarti usaha layak untuk dijalankan.

2. $\mathrm{B} / \mathrm{C}=1$ berarti usaha yang dijalankan dalam kondisi titik impas.

3. $\mathrm{B} / \mathrm{C}<1$ usaha tidak menguntungkan dan tidak layak, secara sistematis $B / C$ rasio dapat dirumuskan sebagai berikut sebagai berikut :

$$
\mathrm{B} / \mathrm{C}=
$$

Total Pendapatan Usaha Budidaya Ikan Lele SangkuriangASIL DAN PEMBAHASAN

Total Biaya Usaha Budidaya Lele Sangkuriang

\section{Break Even Point}

Soekartawi (2006) ada dua jenis perhitungan BEP, yaitu BEP produksi dan BEP harga produksi, dirumuskan sebagai berikut :

1. $\mathrm{BEP}$ produksi $(\mathrm{Kg})=$ total biaya $(\mathrm{Rp})$

harga Jual (Rp)

2. $\mathrm{BEP}$ harga $(\mathrm{Rp})=$ total biaya (Rp)

harga Jumlah produksi (Rp)

Payback Pariod (PP)

Tabel 3. Identitas Pembudidaya Lele Sangkuriang Menggunakan Teknologi Bioflok di Kecamatan Jekan Raya Kota Palangka Raya

\begin{tabular}{llll}
\hline No. & Kriteria Profil & Pembudidaya I & Pembudidaya II \\
\hline 1. & Umur (Tahun) & 32 & 27 \\
2. & Pendidikan terakhir & S1 Teknik & S1 Pertanian \\
3. & Jumlah anak (Orang) & 2 orang & Baru menikah \\
4. & Status kepemilikan usaha & Milik sendiri & Dinas Perikanan \\
5. & Luas tempat usaha & $20 \times 40 \mathrm{~m}^{2}$ & $70 \times 100 \mathrm{~m}^{2}$ \\
6. & Fungsi lain lahan budidaya & Tempat tinggal & $\begin{array}{l}\text { Balai } \\
\text { pengembangan }\end{array}$ \\
& & & ikan air tawar \\
7. & Pekerjaan lain & Karyawan & PNS \\
& & perusahaan & \\
8. & Biaya PBB (Rp/Tahun) & Rp. 100.000 & Rp.100.000 \\
9. & Jumlah kolam (Unit) & 2 & 3 \\
10. & Alamat usaha & Jln. lele VII no 46 & Jln. Yosudarso \\
& & & (depan Hotel \\
& & & Dandang Tingan) \\
\hline
\end{tabular}

Sumber: Data Primer, 2020

b. Pengalaman Usaha Budidaya

Usaha budidaya ikan lele sangkuriang yang dilakukan oleh Pembudidaya I sudah berjalan hampir
Menurut Dwi Rosalina (2013) Perhitungan payback period untuk suatu usaha budidaya ikan lele sangkuriang dapat dilakukan dengan rumus sebagai berikut :

$$
\begin{gathered}
\frac{\text { nilai investasi usaha budidaya ikan lele }}{\text { arus kas usaha budidaya ikan lele }} \times 1 \\
\text { tahun }
\end{gathered}
$$$$
\mathrm{Pp}=
$$

\section{Karakteristik Pembudidaya Ikan Lele Sangkuriang}

a. Identitas Pembudidaya

Terdapat dua pembudidaya ikan lele sangkuriang menggunakan teknologi bioflok yang dijadikan Pembudidaya I dan Pembudiya II yang masih aktif di Kecamatan Jekan Raya Kota Palangka Raya dengan identitas sebagai berikut : dua tahun dimulainya usaha budidaya pada pertengahan tahun 2018. Pada awal memulai usaha budidaya Pembudidaya I melakukan beberapa 
kali percobaan budidaya ikan lele menggukanan teknologi bioflok dimana hasil yang diperoleh tidak optimal, seiring berjalannya waktu Pembudidaya I merubah cara pengolahan kolam dan mengatur kadar air yang sesuai dengan ikan lele sehingga angka mortalitas ikan lele dapat ditekan

\section{Biaya Usaha Pada pembudidaya} I

Pada usaha budidaya Pembudidaya I terdapat dua macam biaya yaitu biaya opresional dan biaya investasi, berikut ini uraian dari biaya operasional usaha budidaya Pembudidaya I dapat dilihat pada tabel 4 antara lain sebagai berikut :

Tabel 4. Biaya Operasional Usaha Budidaya Ikan Lele Sangkuriang Pembudidaya

\begin{tabular}{|c|c|c|c|c|}
\hline $\begin{array}{l}\text { Jenis } \\
\text { Biaya }\end{array}$ & Uraian Biaya & Jumlah & Satuan & Nilai (Rp) \\
\hline \multirow{3}{*}{$\begin{array}{l}\text { Biaya } \\
\text { Tetap }\end{array}$} & a. Biaya Penyusutan & 11 & Item & 1.143 .000 \\
\hline & b. Tenaga Kerja & 1 & $\mathrm{HOK}$ & 7.000 .000 \\
\hline & c. Pajak & 12 & Bulan & 100.000 \\
\hline \multirow{4}{*}{$\begin{array}{l}\text { Biaya } \\
\text { variabel }\end{array}$} & a. Pakan & 40 & Karung & 4.800 .000 \\
\hline & b. Listrik & 500 & Watt & 1.200 .000 \\
\hline & $\begin{array}{l}\text { c. Probiotik MAXI } \\
\text { Grow } 1\end{array}$ & 4 & Botol & 280.000 \\
\hline & d. bibit & 2500 & Ekor & 20.000 .000 \\
\hline
\end{tabular}

Sumber : Data Primer, 2020

Pada Tabel 4 diatas dapat dilihat bahwa total biaya operasional sebanyak Rp.35.523.000 merupakan total dari keseluruhan biaya produksi tiap periode budidaya, dimana usaha budidaya Pembudidaya I terdsapat empat kali periode budidaya.

Jumlah karung pakan yang digunakan seperti yang terlihat pada Tabel 5.2 terdapat 40 karung dimanan harga 1 karung pakan dengan berat sebesar $40 \mathrm{Kg}$ sebesar Rp. 120.000 pada satu kali periode budidaya jumlah pakan yang dibutuhkan 5 karung/kolam karena dua kolam sehingga umlah karung pakan yang dibutuhkan untuk satu kali periode budiaya adalah 10 karung, sehingga pada 4 kali periode budidaya jumlah pakan yang digunakan mencapai 40 karung untuk kedua kolam. Jumlah listrik yang digunakan untuk kolam ikan lele sudah dihitung terpisah dari pemakaian listrik rumah tangga sehingga diasumsikan 500 watt dari penggunaan 2 aerator super silent dan bola lampu. Untuk rincian biaya operasional per siklus produksi dapat dilihat pada lampiran II, sedangkan untuk uraian biaya investasi dapat dilihat pada Tabel 5 antara lain sebagai berikut :

Tabel 5 Biaya Investasi Usaha Budidaya Ikan Lele Sangkuriang Milik Pembudidaya I 


\begin{tabular}{|c|c|c|c|c|c|c|}
\hline No. & Uraian Biaya & Jumlah & $\begin{array}{l}\text { Umur } \\
\text { Ekonomi } \\
\text { (Tahun) }\end{array}$ & $\begin{array}{l}\text { Nilai Alat } \\
\text { Investasi } \\
\text { (Rp) }\end{array}$ & $\begin{array}{l}\text { Nilai } \\
\text { Residu } \\
\text { (Rp) }\end{array}$ & $\begin{array}{r}\text { Biaya } \\
\text { Penyusutan } \\
(\mathrm{Rp})\end{array}$ \\
\hline \multirow{2}{*}{1} & Bangunan & 2 unit & 5 & 4.000 .000 & 500.000 & \\
\hline & Kolam & & & & & 700.000 \\
\hline 2 & Cangkul & 1 buah & 5 & 40.000 & - & 8.000 \\
\hline \multirow{2}{*}{3} & Pipa pralon & 2 & 5 & 80.000 & - & \\
\hline & $2.5 \mathrm{inch}$ & batang & & & & 16.000 \\
\hline 4 & $\begin{array}{l}\text { Sambungan } \\
\text { pipa pipa } 1 / 2 \\
\text { inch }\end{array}$ & 5 buah & 5 & 25.000 & - & 5.000 \\
\hline \multirow{2}{*}{5} & Pipa pralon & 6 & 5 & 140.000 & - & \\
\hline & $1 / 2$ inch & batang & & & & 28.000 \\
\hline 6 & $\begin{array}{l}\text { Aerator } \\
\text { yamanao } \\
\text { super silent } \\
\text { Ap }\end{array}$ & 2 buah & 5 & 600.000 & 10.000 & 118.000 \\
\hline 7 & $\begin{array}{l}\text { Pompa Air } \\
\text { Hitaci }\end{array}$ & 1 buah & 5 & 400.000 & 10.000 & 78.000 \\
\hline 8 & Bola Lampu & 1 buah & 5 & 50.000 & - & 10.000 \\
\hline 9 & Ember sortir & 3 buah & 1 & 120.000 & - & 120.000 \\
\hline \multirow[t]{2}{*}{10} & Ember biasa & 3 buah & 1 & 60.000 & - & 60.000 \\
\hline & Jumlah & & & 5.515 .000 & 520.000 & 1.143 .000 \\
\hline
\end{tabular}

Sumber : Data Primer, 2020

\section{Penerimaan dan Pendapatan Usaha}

Usaha budidaya ikan lele sangkuriang Pembudidaya I mempunyai Jumlah kolam sebanyak 2 unit, dalam proses budidayanya terdapat empat kali siklus budidaya atau empat kali perode panen dimana dalam periode pertama ke perode kedua mempunyai rentangan waktu tiga bulan dari penebaran bibit sampai siap panen. Berikut ini rincian pendapatan usaha Pembudidaya I yang telah dijumlahkan selama empat kali periode budidaya :

Tabel 6. Rincian Produksi dan Pendapatan Usaha Budidaya Ikan Lele Sangkriang Milik Pembudidaya I

\begin{tabular}{cll}
\hline No. & Uraian Pendapatan & Satuan \\
\hline 1 & Jumlah kolam & 2 unit \\
2 & Produksi kolam / periode & $800 \mathrm{Kg}$ \\
3 & Total produksi dari suluruh perode budidaya & $3200 \mathrm{Kg}$ \\
4 & Harga & Rp. $30.000 / \mathrm{Kg}$ \\
5 & Total biaya usaha & Rp. 40.038 .000 \\
6 & Penerimaan & Rp. 96.000 .000 \\
7 & Pendapatan & Rp. 55.962 .000 \\
\hline
\end{tabular}

Sumber : Data primer, 2020 
Dari Tabel 6 bahwa total produksi sebanyak $3200 \quad \mathrm{Kg}$ merupakan total produksi selama empat kali perode budidaya dimana dalam satu kali periode budidaya Pembudidaya I menghasilkan ikan lele sebanyak $800 \mathrm{Kg} /$ siklus produksi.

\section{Biaya Usaha Pembudidaya II}

Pada usaha budidaya Pembudidaya II terdapat dua bentuk biaya yaitu biaya operasional yang meliputi biaya tetap dan biaya variabel serta biaya investasi. Total biaya usaha budidaya Pembudidaya II dapat mencapai ratusan juta hal ini dikarenakan jumlah kolam serta fasilitas pendukung kolam seperti pembuatan atap berskala besar untuk menutupi kolam, pembuatan pagar sekeliling kolam, pengecoran lantai tempat bangunan kolam.

Tabel 7. Biaya Operasional Usaha Budidaya Ikan Lele Sangkuriang Pembudidaya II / Tahun

\begin{tabular}{llllr}
\hline Jenis Biaya & Uraian Biaya & Jumlah & Satuan & Nilai (Rp) \\
\hline \multirow{5}{*}{ Biaya Tetap } & $\begin{array}{l}\text { a.Biaya } \\
\text { penyusutan Alat } \\
\text { b. Tenaga Kerja }\end{array}$ & 10 & Item & 1.824 .000 \\
& $\begin{array}{l}\text { c. Pajak } \\
\text { a. Pakan HI-PRO- }\end{array}$ & 12 & HOK & 6.200 .000 \\
& VITE 781 & & Bulan & 100.000 \\
\hline \multirow{5}{*}{$\begin{array}{l}\text { Biaya } \\
\text { variabel }\end{array}$} & b. Listrik & 500 & Karung & 5.700 .000 \\
& c. Probiotik EM 4 & 4 & Watt & 1.560 .000 \\
& d. Minyak pompa & 8 & Botol & 360.000 \\
& air & & Liter & 80.000 \\
& e. Bibit & 2500 & Ekor & 30.000 .000 \\
\hline
\end{tabular}

Sumber : Data Primer, 2020

Dari Tabel 8 diatas dapat dilihat bahwa jumlah biaya operasional sebanyak Rp. 45.824 .000 merupakan total biaya keseluruhan dari semua siklus produksi dimana dalam siklus

Usaha budidaya ikan lele sangkuriang Pembudidaya II mempunyai Jumlah kolam sebanyak 3 unit, dalam proses budidayanya terdapat empat kali siklus budidaya atau empat kali perode panen dimana dalam periode pertama ke perode kedua mempunyai rentangan waktu tiga bulan dari penebaran bibit sampai siap panen. Berikut ini rincian pendapatan usaha Pembudidaya II yang telah dijumlahkan selama empat kali periode budidaya sehingga untuk mempermudah menganalisis biaya usaha maka difokuskan menghitung biaya yang dikeluar pada tiga kolam yang digunakan dalam budidaya ikan lele sangkuriang. berikut ini uraian biaya usaha budidaya Pembudidaya II dapat dilihat pada Tabel 7 dibawah ini :

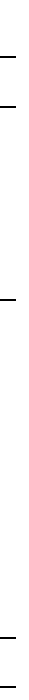

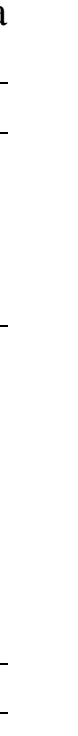


Tabel 8 Uraian Biaya Investasi Usaha Budidaya Ikan Lele Sangkuriang Pembudidaya II

\begin{tabular}{|c|c|c|c|c|c|c|}
\hline No. & Uraian Biaya & Jumlah & $\begin{array}{c}\text { Umur } \\
\text { Ekonomi } \\
\text { (Tahun) }\end{array}$ & $\begin{array}{r}\text { Nilai Alat } \\
\text { Investasi } \\
(\mathrm{Rp}) \\
\end{array}$ & $\begin{array}{l}\text { Nilai } \\
\text { Residu } \\
(\mathrm{Rp}) \\
\end{array}$ & $\begin{array}{c}\text { Biaya } \\
\text { Penyusutan } \\
\text { (Rp) }\end{array}$ \\
\hline 1 & $\begin{array}{l}\text { Bangunan } \\
\text { Kolam }\end{array}$ & 3 unit & 5 & 6.000 .000 & 500.000 & 1.100 .000 \\
\hline 2 & $\begin{array}{l}\text { Pipa prolon } \\
2.5 \text { inch }\end{array}$ & $\begin{array}{l}12 \\
\text { meter }\end{array}$ & 5 & 120.000 & - & 24.000 \\
\hline 3 & $\begin{array}{l}\text { Pipa prolon } \\
1 / 2 \text { inch }\end{array}$ & $\begin{array}{l}32 \\
\text { meter }\end{array}$ & 5 & 120.000 & - & 24.000 \\
\hline 4 & $\begin{array}{l}\text { Sambungan } \\
\text { pipa } 1 / 2 \text { inch }\end{array}$ & 10 buah & 5 & 50.000 & - & 10.000 \\
\hline 5 & $\begin{array}{l}\text { Selang } \\
\text { silikon } 6 \text { x } 8 \\
\text { mm }\end{array}$ & 1 roll & 5 & 100.000 & - & 20.000 \\
\hline 6 & Aerator & 3 buah & 5 & 900.000 & 10.000 & 178.000 \\
\hline 7 & $\begin{array}{l}\text { Pompa Air } \\
\text { Water PUM } \\
2.5 \text { inch }\end{array}$ & 1 buah & 5 & 1.300 .000 & 10.000 & 240.000 \\
\hline 8 & Bola Lampu & 1 buah & 5 & 50.000 & - & 20.000 \\
\hline 9 & Ember sortir & 4 buah & 5 & 140.000 & - & 28.000 \\
\hline 10 & Ember biasa & 3 buah & 5 & 60.000 & - & 12.000 \\
\hline & & & & 8.840 .000 & 520.000 & 1.824 .000 \\
\hline
\end{tabular}

Sumber : Data Primer, 2019

\section{Pendapatan Usaha} Pembudidaya II

Usaha yang dijalankan oleh Pembudidaya II merupakan usaha yang dibawah naugan Dinas Kelautan dan Perikanan Provinsi Kalimantan Tengan yang bertujuan untuk contoh dan tempat penelitian bagi masyarakat, dari 16 kolam bioflok yang dikelola oleh Pembudidaya II terdapat 3 kolam yang digunakan untuk budidaya ikan lele dan 13 kolam lainya digunakan untuk pembesaran ikan patin, nila, pembibitan patin dan nila dan beberapa jeni ikana air tawar lainnya. Pada pemasaran ikan lele Pembudidaya II tidak sortir seperti Pembudidaya I dimanan penjualan ikan lele langsung kepada pengupul dengan harga borongan yang sudah disepakati.

Tabel 9. Total Produksi dan Pendapatan Usaha Budidaya Ikan Lele Sangkriang Pembudidaya II

\begin{tabular}{cll}
\hline No. & Uraian Pendapatan & Satuan \\
\hline 1 & Jumlah kolam & 3 unit \\
2 & Produksi kolam / periode & $1200 \mathrm{Kg}$ \\
3 & Total produksi dari suluruh perode budidaya & $4800 \mathrm{Kg}$ \\
4 & Harga & Rp. $25.000 / \mathrm{Kg}$ \\
5 & Total biaya usaha & Rp. 54.664 .000 \\
6 & Penerimaan usaha & Rp. 120.000 .000 \\
\hline
\end{tabular}


$7 \quad$ Pendapatan usaha

Rp. 65.336 .000

Sumber : Data Primer, 2020

Dari Tabel 9 total produksi ikan lele Responden II sebanyak $4800 \mathrm{Kg}$ merupakan total produksi dari keseluruhan siklus produksi dimana Responden II melakukan empat kali siklus produksi yang mempunyai interval waktu selama tiga bulan pada tiap - tiap sikus, dalam satu kali siklus produksi menghasilkan 400 $\mathrm{Kg} /$ kolam dari 2500 bibit yang ditebar karena Responden II mempunyai 3 kolam sehingga jumlah ikan lele yang diproduksi Responden II dalam satu siklus produksi sebanyak $1200 \mathrm{Kg}$

\section{Kelayak Usaha Budidaya}

Hasil analisis kelayakan usaha budidaya menunjukan layak atau tidaknya usaha yang dijalankan oleh Responden I dan , Responden II dengan adanya analisis kelayakan ini akan akan membuat kesimpulan yang berkatian dengan keberlanjutan usaha. Berikut ini hasil analisis kelayakan usaha Responden I dan Responden II:

Tabel 10. Hasil Analisis Kelayakan Usaha Budidaya Ikan Lele menggunakan Teknologi Biolok Milik Pembudidaya I dan Pembudidaya II

\begin{tabular}{llll}
\hline No. & $\begin{array}{l}\text { Parameter } \\
\text { Perbandingan }\end{array}$ & Pembudidaya I & Pembudidaya II \\
\hline 1 & Produksi & $3200 \mathrm{Kg}$ & $4800 \mathrm{Kg}$ \\
2 & Harga & Rp. 30.000 & Rp. 25.000 \\
3 & Penerimaan & Rp. 96.000 .000 & Rp. 120.000 .000 \\
4 & Total Biaya & Rp. 33.038 .000 & Rp. 48.804 .000 \\
5 & Pendapatan & Rp. 63.110 .000 & Rp. 71.365 .000 \\
6 & R/C Rasio & $2,3>1$ & $2,1>1$ \\
7 & B/C Rasio & $1,3>1$ & $1,1>1$ \\
8 & BEP Produksi & $1.334 \mathrm{Kg}$ & $2.186 \mathrm{Kg}$ \\
& BEP Harga & Rp. 12.511 & Rp. 11.388 \\
9 & Payback Pariod & 4 Bulan & 3,2 bulan \\
\hline
\end{tabular}

Sumber : Data Primer, 2020

Nilai R/C rasio pada usaha Pembudidaya I sebesar 2,3> 1 artinya setiap modal yang dikelurkan sebesar 1 rupiah akan kembalinya uang 2,3 rupiah, pada nilai $\mathrm{B} / \mathrm{C}$ rasio Pembudidaya I sebesar 1,3>1 artinya setiap biaya yang dikelurkan sebanyak 1 rupiah akan memperoleh manfaat usaha sebesar 1,3 rupiah. Pada nilai Break Even point usaha Pembudidaya I sudah layak dijalankan dimana produksi ikan lele Responden I sebanyak $3200 \mathrm{Kg}>$ dari BEP produksi sebanyak $1.344 \mathrm{Kg}$ dan harga jual ikan lele Pembudidaya I sebesar Rp. 30.000/Kg > dari nilai BEP harga sebesar Rp. 12.511.

Nilai R/C rasio usaha budidaya Pembudidaya II sebesar $2,1>1$ atrinya setiap biaya yang dikeluarkan sebesar 1 rupiah akan kembali sebesar 2,1 rupiah, sedangakan untuk nilai $\mathrm{B} / \mathrm{C}$ rasio sebesar $1,1>1$ artinya setiap biaya yang dikelurkan sebesar 1 rupiah akan memperoleh manfaat dari usaha yag dijalankan sebesar 1,1 rupiah, dari nilai Break Event point usaha Pembudidaya II sudah layak 
untuk dijalankan, karena jumlah produksi ikan lele yang dihasilkan Pembudidaya II sebanyak $4800 \mathrm{Kg}$ > dari nilai BEP produksi sebanyak $2.186 \mathrm{Kg}$, dan harga jual ikan lele Pembudidaya II sebesar Rp. 25.000/Kg > dari nilai BEP harga sebesar Rp. 1.388.

\section{Kesimpulan}

\section{PENUTUP}

Berdasarkan hasil penelitian kelayakan usaha budidaya ikan lele sangkuriang menggunakan teknologi biolok di Kecamatan Jekan Raya Kota Palangka Raya makan dapat diambil beberapa kesimpulan antara lain sebagai berikut :

1. Budidaya ikan lele sangkuriang menggunakan teknologi biflok di Kecamatan Jekan Raya Kota Palangka Raya yang dilakukan oleh Pembudidaya I dan Pembudidaya II mempunyai cara budidaya dan sistem pemasaran yang berbeda meskipun sama - sama budidaya menggunakan teknologi bioflok. Pada teknis pemasaran Pembudidaya I lebih mengutamakan nilai tambah dari hasil produksi ikan lele dengan meningkatkan harga jual ikan lele per kilo gramnya dengan cara pengolahan seperti packing (dikemas) sehinga ikan lele yang dijual sudah siap untuk dimasak, sedangkan Pembudidaya II menjual hasil produksi ikan lele dengan sistem borongan kepada pengepul siehingga harga jualikan lele yang diperoleh tidak terlalu tinggi.

2. Hasil analisis kelayakan usaha menunjukan bahwa usaha Pembudidaya I dan Pembudidaya II dinyatakan layak untuk diusahakan karena sudah memenuhi beberapa kriteria kelayakan usaha, secara teknis Pembudidaya I lebih aktif mengelola hasil produksinya dibandingkan Pembudidaya II, sehingga mempengaruhi nilai jual ikan lele yang berdampak pada meningkatnya harga jual.

\section{DATAR PUSTAKA}

A.T. Mosher, Menggerakkan dan Membangun Pertanian, Jakarta : Jayaguna, 1968

Allen, K.O. 1974. Effects of stocking density and water exchange rate on growth and survival of chanel catfish ictalurus punctatus (Rafinesque) in circular thanks Aquaculture.

Abdi Tri Sulistyo, Endang Chumaidiyah, Aji Pamoso, 2015. Analisis Kelayakan Usaha Pengembangan Budidaya Ikan Lele Untuk Perusahaan X di Kabupaten Bandung. Jurnal e-Proceeding of Engineering. Vol.2, No.2

Badan Pusat Statistik Provinsi Kalimantan Tengah 2017. Kalimantan Tengah Dalam Angka 2018.

Dinas Perikanan Kota Palangka Raya, 2019. Laporan Tahunan Statistik Perikanan Budidaya Provinsi Kalimantan Tengah 2018. Palangka Raya.

Dwi Rosalina, 2014. Analisis Kelayakan Usaha Budidaya Ikan Lele di Kolam Terpal di Desa Namang Kabupaten Bangka Tengah. Maspari Journal. Vol 6. No 20-24.

Fahrudin, 2018. Analisis Kelayakan Teknis Dan Finansial Usaha Budidaya Ikan Lele (Clarias sp.) Menggunakan Sistem Bioflok. Skripsi. Fakultas 
Pertanian. Universitas Gajah Mada. Yogyakarta.

Farikhah. 2012. Jenis - Jenis Ikan Lele Yang dibudidayakan di Indonesia.

(https://www.academia.edu/42 33551/Jenis-

Jenis_Ikan_Lele_Yang_Dibudi dayakan_Di_Indonesia).

Faridah. Selvie Diana \& Yuniati. 2019. Budidaya Ikan Lele dengan Metode Bioflok Pada Peternakan Ikan Lele Konvensional. Jurnal Pengabdian Kepada

Masyarakat. Vol 1, No 2.

(https://jorunal.illininstiture.co m/index.php/caradde).

I Nyoman Radiarta, Saputra Adang dan Priyono Bambang, 2005. Identifikasi Kelayakan Lahan Budidaya dalam Keramba Jaring Apung dengan Aplikasi Sistem Informasi Geografi di Teluk Pangpang, Jawa Timur. Jurnal Peneliti Perikanan Indonesia. Vol 3, No 11.

Jamaludin, 2015. Analisis Pendapatan Usaha Pembesaran Ikan Lele Sangkuriang (Clarias gariefenus). Skripsi. Fakultas Sain dan Teknologi. Universitas Islam Negeri Syarif Hidayatullah. Jakarta.
Khairuman, Khairul Amri . Panen Rupiah dari Budi Daya Lele. Jakarta: Erlangga, 2013.

Ken Suratiyah, 2008. Ilmu Usahatani. Penebar Swadaya. Jakarta.

Muhammad Isa, 2014. Analisa Usaha Budidaya Pembesaran Ikan Lele Sangkuriang (Clarias Sp) Di Kabupaten Aceh Barat Daya. Skripsi. Aceh.

Rahardi dan Hartono. Agribisnis Peternakan. Jakarta : Penebar Swadaya, 2003.

Soeharjo, A dan Patong. 1973. Sendi - Sendi Pokok Usahatani. Jurusan Ilmu Sosial Ekonomi Pertanian. Institut Pertanian Bogor : Bogor.

Soekartawi. 2006. Analisis Usahatani. Jakarta. Universitas Indonesia

Sanusi Bexticia. 2000. Pengantar Evaluasi Proyek. Fakultas Ekonomi universitas Indonesia. Jakarta

sSudana, 2013. Kelayakan Usaha Budidaya Ikan Lele Dumbo (Clarias Gariepinus) dan Pengaruhnya Terhadap Tingkat Pendapatan Petani Ikan Leledi Kabupaten Tabanan. Jurnal Manajemen Agribisnis. Vol. 1, No.1. 